\title{
ANALISIS FAKTOR PENGARUH DOMINAN PERACANGAN PENERAPAN MODEL RENCANA INSENTIF PADA MATERIAL SISA
}

\author{
Triongko Agatha Bayuaji ${ }^{1}$, dan Basuki Anondho ${ }^{2}$ \\ ${ }^{1}$ Program Studi Sarjana Teknik Sipil, Universitas Tarumanagara, Jl. Letjen S. Parman No.1 Jakarta \\ triongko.325170041@stu.untar.ac.id \\ ${ }^{2}$ Program Studi Sarjana Teknik Sipil, Universitas Tarumanagara, Jl. Letjen S. Parman No.1 Jakarta \\ basukia@ft.untar.ac.id
}

Masuk: 12-08-2021, revisi: 06-08-2021, diterima untuk diterbitkan: 19-08-2021

\begin{abstract}
The incentive is an additional compensation given in monetary or non-monetary form so that the parties involved in a job try their best to complete their work properly without reducing the quality of work. The purpose of this study is to find out what dominant factors need to be considered in implementing an incentive plan and to find out whether this incentive plan model affects the residual material. This research was conducted by processing primary data in the form of a Likert scale questionnaire. A Likert scale of 1-5 is used to measure the level of influence of an identified factor on the incentive plan. In the process, this research uses the Factor Analysis Method with a significance level of 5\% and is assisted by the application of Statistics Product and Service Solutions (SPSS) or a statistical package for social sciences to test and calculate data. Based on the research results obtained 3 dominant factors that need to be considered in the implementation of the incentive plan, in the research interview some experts agreed and disagreed with this incentive plan model for the reduction of waste material based on several considerations.
\end{abstract}

Keywords: Incentive plan, Incentive, Material waste

\begin{abstract}
ABSTRAK
Insentif adalah suatu kompensasi tambahan yang diberikan dalam bentuk moneter atau nonmoneter supaya pihakpihak yang terlibat dalam suatu pekerjaan berusaha semaksimal mungkin dapat menyelesaikan pekerjaannya dengan baik tanpa mengurangi kualitas kerja. Tujuan dari penelitian ini adalah untuk mengetahui faktor-faktor dominan apa saja yang perlu dipertimbangkan dalam menerapkan rencana insentif dan mengetahui apakah model rencana insentif ini mempengaruhi material sisa. Penelitian ini dilakukan dengan mengolah data primer berupa angket skala likert. Skala likert 1-5 digunakan untuk mengukur tingkat pengaruh suatu faktor yang diidetifikasi terhadap rencana insentif. Dalam pengerjaannya, penelitian ini menggunakan Metode Analisis Faktor dengan taraf signifikansi 5\% dan dibantu dengan aplikasi Statistics Product and Service Solutions (SPSS) atau paket statistik untuk ilmu sosial untuk menguji dan menghitung data. Berdasarkan hasil penelitian didapat 3 faktor dominan yang perlu diperhatikan dalam penerapan rencana insentif, dalam wawancara penelitian terdapat ahli yang setuju dan tidak setuju dengan model rencana insentif ini untuk pengurangan material sisa berdasarkan beberapa pertimbangan.
\end{abstract}

Kata Kunci: Rencana insentif, Insentif, Material sisa

\section{PENDAHULUAN}

Meningkatnya produksi sampah di seluruh dunia merupakan masalah utama yang membutuhkan strategi pengelolaan yang berfokus pada lingkungan yang berkelanjutan. Industri konstruksi sendiri menjadi salah satu penyumbang utama masalah ini karena menghasilkan material dan limbah konstruksi dalam jumlah besar (Mahpour \& Mortaheb, 2018), yang berarti material merupakan masalah yang dapat merusak lingkungan.

Namun banyak orang yang tidak menyadarinya, penggunaan dan pengeolaan material ini tidak diperhatikan, sehingga sering terjadi pemborosan baik dari penggunaan material tersebut secara berlebihan (Gavilan et al, 1994), dilihat dari jumlah material sisa yang dihasilkan tidak sedikit, industri konstruksi di dunia menghasilkan setidaknya 35\% dari total limbah padat (Llatas 2011) dan 10 - 30\% dari timbunan limbah (Begum et al, 2009).

Efek yang dihasilkan tentunya sangat terasa, terutama di sektor biaya karena material sisa memegang peranan penting di sektor tersebut (Aulia et al, 2016). Tidak hanya di sektor biaya, tempat-tempat penyimpanan sampah sekarang terisi dengan sangat cepat, dan tempat pembuangan sampah untuk bahan-bahan sampah langka (Gavilan 
et al, 1994). Tentu akan sangat berpengaruh terhadap lingkungan. (Devia et al, 2010).

Oleh karena itu, harus ada solusi yang dapat mengurangi besarnya jumlah sisa konstruksi atau material sisa yang terus menjadi polemik hingga saat ini. Salah satu cara yang dapat digunakan untuk meminimalisir sisa material pada konstruksi bangunan adalah dengan mencari penyebab utamanya.

Namun, penelitian ini akan fokus pada penerapan rencana insentif dalam menekan masalah tersebut. Baru-baru ini, rencana insentif semakin banyak diterapkan untuk menyelaraskan tujuan dalam pelaksanaan proyek konstruksi (Tang et al, 2008). Pada bulan Desember 2005, pemerintah Hong Kong merancang skema pengisian material sisa untuk mendanai rencana insentif serta mempromosikan penggunaan kembali dan mendaur ulang material sisa untuk mengurangi jumlah material sisa konstruksi (Poon et al, 2013). Penggunaan insentif ini juga merupakan sarana motivasi yang dapat mendorong pekerja untuk bekerja secara maksimal (Herliana et al, 2017). Insentif tidak hanya digunakan sebagai motivasi bagi kontraktor tetapi juga dapat digunakan untuk menghasilkan keselarasan dengan tujuan proyek (Bower et al, 2002). Insentif keuangan menggunakan imbalan moneter untuk merangsang peningkatan kinerja atau produksi serta insentif psikologis sebagai lawan dari insentif keuangan, juga merupakan sarana yang valid untuk menghasilkan peningkatan produksi dan / atau kinerja (Roger et al, 1992).

Penelitian ini melakukan studi literatur dengan menerapkan pendekatan rencana insentif terhadap permasalahan material sisa yang sering terjadi bahkan telah menjadi bagian dari konstruksi, diharapkan pendekatan ini dapat mengurangi jumlah material sisa, maka dari itu sebelum diterapkannya rencana insentif perlu dilakukannya penelitian tentang faktor-faktor apa saja yang perlu dipertimbangkan dalam penerapan rencana insentif.

\section{Definisi Material Sisa}

Material sisa didefinisikan sebagai suatu hal yang berlebih dan di isyaratkan baik berupa hasil pekerjaan maupun material konstruksi yang tersisa, tercecer, atau rusak sehingga tidak dapat digunakan lagi sesuai fungsinya. Ada banyak faktor yang menjadi sumber terjadinya sisa material konstruksi antara lain pelaksanaan, pengadaan material, penanganan material, residul, desain dan lain-lain misal pencurian (Devia et al, 2010).

\section{Jenis Material yang Digunakan Dalam Konstruksi}

Material yang digunakan dalam konstruksi dapat dibedakan menjadi 2 bagian besar (Devia et al, 2010), yaitu:

1. Consumable Material adalah suatu material yang pada akhirnya akan menjadi bagian dari struktur fisik bangunan, misalnya: semen, pasir, kerikil, batu bata, besi tulangan, baja, dan lain-lain.

2. Non-consumable material adalah suatu material penunjang dalam proses konstruksi, dan bukan merupakan bagian fisik dari bangunan setelah bangunan tersebut selesai, misalnya: perancah, bekisting, dan dinding penahan sementara.

Didalam penelitian (Tchobanoglous et al, 1993) sisa material konstruksi dapat dibedakan menjadi 2 bagian selama pelaksanaan konstriksi, Sebagai berikut:

1. Demolition waste adalah sisa material yang timbul dari hasil pembongkaran atau penghancuran bangunan lama.

2. Construction waste adalah sisa material konstruksi yang berasal dari pembangunan atau renovasi bangunan milik pribadi, komersil dan struktur lainnya. Sisa material tersebut berupa sampah yang terdiri dari beton, batu bata, plesteran, kayu, sirap, pipa dan komponen listrik.

\section{Definisi Insentif}

Defenisi insentif adalah suatu tambahan penghasilan yang diberikan sebagai penghargaan dalam bentuk moneter/non-moneter, supaya pihak yang terlibat dalam proyek konstruksi termotivasi untuk melakukan segala upaya agar dapat menyelesaikan pekerjaan lebih cepat dari waktu yang diperjanjikan dengan tetap menjaga mutu sesuai dengan yang dipersyaratkan (Sarli \& Adianto, 2017).

Mustafa (2017) di dalam bukunya mendefinisikan insentif sebagai berikut, insentif sebagai sarana motivasi, dapat diberi batasan perangsang atau pendorong yang diberikan dengan sengaja kepada para pekerja agar dalam diri mereka timbul semangat yang lebih besar untuk berprestasi bagi organisasi. Dilain hal insentif finansial adalah Ganjaran finansial yang diberikan kepada karyawan yang tingkat produksinya melampaui standar yang sudah ditetapkan sebelumnya.

\section{Jenis-Jenis Insentif}

Menurut Putra et al (2017) mengemukakan pada dasarnya, insentif dapat dibedakan menjadi dua jenis, yang pertama insentif finansial dan insentif non finansial. Insentif finansial merupakan insentif yang berbentuk pendapatan, dimana insentif digunakan untuk memenuhi kebutuhan hidup dan dapat dinilai dengan uang, diantaranya meliputi 
gaji atau upah yang pantas, bagi keuntungan dari perusahaan/instansi dan soal-soal kesejahteraan yang meliputi pemeliharaan kesehatan, rekreasi, jaminan hari tua dan sebagainya. Sedangkan insentif non finansial, merupakan insentif merupakan suatu penghargaan yang biasanya bersifat psikologis. Sedangkan bentuknya berupa, menumbuhkan rasa kebanggaan dan kesenangan terhadap karyawan, memberikan simpati dan perlakuan yang wajar kepada karyawan, memberikan kesempatan untuk dipromosikan, kesempatan yang sama untuk mendapatkan pelatihan, adanya keamanan dan ketenangan dalam bekerja, serta harapan untuk mendapatkan penghargaan, kesejahteraan yang memadai termasuk keluarganya dalam pengobatan, tunjangan hari tua, asuransi kecelakaan dan lain-lain.

\section{Kuesioner Identifikasi Awal Faktor Dominan}

Pada tahap ini, penulis merangkum beberapa pertanyaan untuk kuesioner terkait penerapan model rencana insentif pada material sisa yang diambil dari referensi untuk menyusun kuesioner sebagai berikut.

Tabel 1. Pertanyaan Kuesioner

\begin{tabular}{|c|c|c|c|}
\hline No & Referensi & Indikator & Poin Pertanyaan \\
\hline 1 & $\begin{array}{l}\text { Mahpour \& Mortaheb, } \\
\text { (2018) }\end{array}$ & Etika profesional & $\begin{array}{c}\text { Etika profesional mempengaruhi } \\
\text { rencana insentif untuk pengurangan } \\
\text { material sisa }\end{array}$ \\
\hline 2 & $\begin{array}{l}\text { Mahpour \& Mortaheb, } \\
\text { (2018) }\end{array}$ & Motivasi & $\begin{array}{c}\text { Tingkat motivasi pekerja lapangan } \\
\text { mempengaruhi rencana insentif untuk } \\
\text { pengurangan material sisa }\end{array}$ \\
\hline
\end{tabular}

Tang et al (2008)

\begin{tabular}{cc} 
Ogwueleka \& Maritz, (2013) & \\
\hline Mahpour \& Mortaheb, & Motivasi \\
(2018) & $\begin{array}{c}\text { Tingkat motivasi stakeholder } \\
\text { mempengaruhi rencana insentif untuk } \\
\text { pengurangan material sisa }\end{array}$
\end{tabular}

Broome et al (2002)

Tang et al (2008)

\begin{tabular}{cc} 
Ogwueleka \& Maritz, (2013) & \\
\hline 4 Mahpour \& Mortaheb, & Lebih efektif \\
(2018) &
\end{tabular}

Sarli \& Adianto, (2017)

\begin{tabular}{|c|c|c|c|}
\hline \multirow[t]{2}{*}{5} & $\begin{array}{c}\text { Mahpour, \& Mortaheb } \\
\text { (2018) }\end{array}$ & Lebih efisien & $\begin{array}{c}\text { material sisa } \\
\text { Efisiensi pekerja lapangan } \\
\text { mempengaruhi rencana insentif untuk } \\
\text { pengurangan material sisa }\end{array}$ \\
\hline & \multicolumn{3}{|l|}{ Sarli \& Adianto, (2017) } \\
\hline \multirow[t]{2}{*}{6} & $\begin{array}{c}\text { Mahpour \& Mortaheb, } \\
\text { (2018) }\end{array}$ & Lebih efisien & $\begin{array}{c}\text { Efisiensi pekerjaan kontraktor } \\
\text { mempengaruhi rencana insentif untuk } \\
\text { pengurangan material sisa }\end{array}$ \\
\hline & \multicolumn{3}{|l|}{ Sarli \& Adianto, (2017) } \\
\hline \multirow[t]{2}{*}{7} & $\begin{array}{c}\text { Mahpour \& Mortaheb, } \\
\text { (2018) }\end{array}$ & Kinerja yang baik & $\begin{array}{l}\text { Kinerja pekerja lapangan yang baik } \\
\text { mempengeruhi rencana insentif untuk } \\
\text { pengurangan material sisa }\end{array}$ \\
\hline & Tang et al (2008) & $\begin{array}{c}\text { Kinerja Proyek yang } \\
\text { Baik }\end{array}$ & \\
\hline
\end{tabular}


(Lanjutan) Tabel 1. Pertanyaan Kuesioner

\begin{tabular}{cccc}
\hline No & Referensi & Indikator & Poin Pertanyaan \\
\hline 8 & $\begin{array}{c}\text { Mahpour \& Mortaheb, } \\
(2018)\end{array}$ & $\begin{array}{c}\text { Menghemat lebih banyak } \\
\text { material sisa }\end{array}$ & $\begin{array}{c}\text { Penerapan rencana insentif secara } \\
\text { meluas untuk membangun proyek akan } \\
\text { menghemat lebih banyak material sisa }\end{array}$ \\
\hline 9 & Mahpour \& Mortaheb, & Anggaran & $\begin{array}{c}\text { Suatu anggaran proyek mempengaruhi } \\
\text { rencana insentif untuk pengurangan } \\
\text { (2018) }\end{array}$ \\
& & $\begin{array}{c}\text { material sisa } \\
\end{array}$
\end{tabular}

Chokor et al (2017)

Sarli \& Adianto, (2017)

\begin{tabular}{|c|c|c|c|}
\hline 10 & $\begin{array}{l}\text { Mahpour \& Mortaheb, } \\
\qquad \text { (2018) } \\
\text { Chokor et al (2017) } \\
\text { Sarli \& Adianto (2017) }\end{array}$ & Biaya proyek & $\begin{array}{c}\text { Biaya proyek mempengaruhi rencana } \\
\text { insentif untuk pengurangan material } \\
\text { sisa }\end{array}$ \\
\hline 11 & $\begin{array}{l}\text { Mahpour \& Mortaheb, } \\
\text { (2018) }\end{array}$ & $\begin{array}{l}\text { Pemanfaatan bahan } \\
\text { ramah lingkungan }\end{array}$ & $\begin{array}{l}\text { Rencana insentif dipengaruhi oleh } \\
\text { penggunaan bahan ramah lingkungan } \\
\text { untuk pengurangan material sisa }\end{array}$ \\
\hline 12 & Ogwueleka \& Maritz, (2013) & Mencapai tujuan kinerja & $\begin{array}{c}\text { Pencapaian tujuan kinerja pekerja } \\
\text { lapangan mempengaruhi rencana } \\
\text { insentif untuk pengurangan material } \\
\text { sisa }\end{array}$ \\
\hline 13 & Poon et al (2013) & Memberikan wawasan & $\begin{array}{c}\text { Wawasan para pekerja lapangan } \\
\text { mempengaruhi rencana insentif untuk } \\
\text { pengruangan material sisa }\end{array}$ \\
\hline 14 & Poon et al (2013) & Memberikan wawasan & $\begin{array}{c}\text { Wawasan para stakeholder } \\
\text { mempengaruhi rencana insetif untuk } \\
\text { pengurangan material sisa }\end{array}$ \\
\hline 15 & Chokor et al (2017) & $\begin{array}{c}\text { Penyelesaian proyek } \\
\text { dengan sedikit masalah }\end{array}$ & $\begin{array}{c}\text { Sedikitnya permasalahan dalam proyek } \\
\text { mempengaruhi rencana insentif untuk } \\
\text { pengurangan material sisa }\end{array}$ \\
\hline 16 & $\begin{array}{l}\text { Karakhan \& Gambatese, } \\
\text { (2018) } \\
\text { Ogwueleka \& Maritz, (2013) } \\
\text { Tang et al (2008) }\end{array}$ & Kualitas Kerja & $\begin{array}{l}\text { Peningkatan kualitas pekerja lapangan } \\
\text { mempengaruhi rencana insentif untuk } \\
\text { pengurangan material sisa }\end{array}$ \\
\hline 17 & $\begin{array}{l}\text { Chokor et al (2017) } \\
\text { Sarli, Adianto (2017) }\end{array}$ & Jadwal Proyek & $\begin{array}{c}\text { Jadwal proyek mempengaruhi rencana } \\
\text { insentif untuk pengurangan material } \\
\text { sisa }\end{array}$ \\
\hline 18 & Chokor et al (2017) & $\begin{array}{c}\text { Penyelesaian proyek } \\
\text { dengan sedikit masalah }\end{array}$ & $\begin{array}{c}\text { Sedikitnya kecacatan yang muncul } \\
\text { pada proyek mempengaruhi rencana } \\
\text { insentif untuk pengurangan material } \\
\text { sisa }\end{array}$ \\
\hline 19 & Sarli \& Adianto, (2017) & Apresiasi & $\begin{array}{c}\text { Rencana insentif dipengaruhi oleh } \\
\text { reputasi dan prestasi perusahaan untuk } \\
\text { pengurangan material sisa }\end{array}$ \\
\hline 20 & Sarli \& Adianto, (2017) & Reputasi dan prestasi & $\begin{array}{l}\text { Rencana insentif tidak dipengaruhi } \\
\text { oleh pemberian sanksi untuk } \\
\text { pengurangan material sisa }\end{array}$ \\
\hline
\end{tabular}




\section{METODE PENELITIAN}

\section{Persiapan Kuesioner}

Pada tahap penyusunan kuesioner, yang dilakukan adalah membuat pertanyaan berdasarkan studi pustaka yang telah dilakukan kemudian dirangkum dan dijadikan pertanyaan untuk kuesioner, setelah itu dilakukan validasi kuesioner ke sejumlah pakar. Validasi pakar dilakukan untuk memperkuat variabel dalam kuesioner yang akan disebarkan ke responden. Adapun jumlah pakar yang diusulkan berjumlah 5 (lima) orang. Dari hasil validasi pakar diperoleh 17 variabel yang disetujui yang kemudian digunakan sebagai variabel dalam kuesioner. Responden yang menjadi target kueisoner adalah project coordinator, project manager, owner perusahaan.

\section{Validasi Pakar}

Pada saat tahapan validasi pakar, hal yang dilakukan ialah dengan bertanya dan meminta pendapat kepada para pakar mengenai penerapan rencana insentif ini dalam mengurangi jumlah material sisa serta meminta pendapat para pakar mengenai faktor faktor yang disajikan pada kuesioner apakah faktor tersebut bisa dijadikan acuan untuk penerapan rencana insentif. Validasi pakar dilakukan dengan memberikan kuesioner yang telah dibuat kepada sejumlah pakar di bidang kontruksi yang bertujuan untuk meminta pendapat para pakar terhadap kuesioner yang telah dibuat. Langkah ini dapat dikatakan sebagai validasi kuesioner sebelum kuesioner di uji cobakan di lapangan, apakah pakar setuju atau tidak setuju bahwa variabel yang ada merupakan faktor-faktor yang perlu dipertimbangkan dalam menerapkan rencana isentif untuk mengurangi material sisa. Adapun jumlah pakar yang diusulkan adalah sejumlah 5 pakar, dengan kriteria bekerja pada perusahaan konstruksi, riwayat pendidikan terakhir minimal S1, berstatus jabatan project manager atau sederajat atau lebih tinggi, memiliki pengalaman kerja selama 10 tahun atau lebih, memiliki pemahaman tentang material sisa dan insentif. Validasi ini dilakukan dengan cara menyebarkan kuesioner dalam bentuk tabel dengan point-point yang berisi pertanyaan apakah para pakar setuju bahwa rencana insentif ini merupakah langkah yang tepat dan dapat mengurangi material sisa. Variabel yang disetujui oleh pakar, maka diberi nilai 1 , sedangkan apabila variabel tidak disetujui oleh pakar maka diberi nilai 0 . Batasan total nilai 4 digunakan dalam menentukan variabel tersebut dapat dipakai atau tidak. Artinya, variabel dapat diterima apabila minimal di setujui oleh 4 pakar. hasil tabulasi dari validasi pakar disusun dalam Tabel 3.2 berikut ini.

Tabel 2. Contoh Tabulasi Validasi Pakar

\begin{tabular}{cccccccc}
\hline Kode & P1 & P2 & P3 & P4 & P5 & Total & Hasil \\
\hline X1 & 1 & 1 & 1 & 1 & 0 & 4 & YA \\
$\ldots$ & $\ldots$ & $\ldots$ & $\ldots$ & $\ldots$ & $\ldots$ & $\ldots$ & $\ldots$ \\
$\ldots$ & $\ldots$ & $\ldots$ & $\ldots$ & $\ldots$ & $\ldots$ & $\ldots$ & $\ldots$ \\
$\mathrm{Xn}$ & 1 & 1 & 1 & 0 & 0 & 3 & TIDAK \\
\hline
\end{tabular}

\section{Pembagian Kuesioner}

Pada saat penyebaran kuesioner yang dilakukan adalah menyebarkan kuesioner kepada beberapa responden yang bekerja di lingkup proyek. Kuesioner akan disampaikan kepada beberapa responden yaitu Quantity Surveyor dan project manager. Kuesioner akan disebarkan melalui media sosial dengan bantuan google form, namun beberapa responden akan menggunakan kertas.

\section{Distribusi Pengumpulan Data Kuesioner}

Pada saat pengumpulan data kuisioner, yang dilakukan adalah dengan mendatangi kembali responden dan menanyakan hasil kuisioner.

\section{Metode Analisis Data}

Teknik analisis faktor adalah metode yang dipakai dalam pelitian analisis data kali ini, hal ini bertujuan untuk menentukan faktor dominan dengan cara mengidentifikasi hubungan antar sejumlah faktor yang saling independen dengan melakukan uji korelasi. Sebelum analisis faktor dilakukan, perlu adanya validasi untuk menentukan layak atau tidaknya data yang didapatkan. Teknik uji validitas yang akan digunakan adalah korelasi Pearson, yaitu dengan mengkorelasikan skor item dengan skor total item tiap variabel, kemudian pengujian signifikan dilakukan dengan 
kriteria menggunakan $\mathrm{r}$ tabel 5\% pada tingkat signifikan 0,05 dengan uji 2 (dua) sisi (Priyatno, 2019). Kemudian dilanjutkan dengan uji reliabilitas yang bertujuan untuk mengetahui konsistensi alat ukur apakah alat ukur yang digunakan dapat diandalkan dan tetap konsisten jika pengukuran tersebut diulang. Metode yang sering digunakan dalam penelitian untuk mengukur skala Likert 1-5 adalah Cronbach's Alpha. Setelah itu, data diuji normalitasnya untuk mengetahui apakah data yang dipergunakan terdistribusi normal. Pada uji ini digunakan teknik Shapiro Wilk karena pada uji kali ini, penulis menggunankan data sebanyak 30 responden sehingga digunakan teknik tersebut. Setelah melalui ketiga uji yang disebutkan barusan, data yang tersisa dan dianggap validlah yang kemudian dipergunakan dalam analisis faktor. Tahapan analisis faktor secara garis besar adalah yang pertama melakukan uji korelasi antar variabel asal dengan tujuan agar penyusutan variabel menjadi lebih sederhana. Kemudian menentukan nilai KMO (Kaiser-Meyer-Olkin) dan dilanjutkan dengan menentukan nilai Meaasure of Sampling Adequence (MSA), yaitu kelayakan untuk seluruh variabel yang diobservasi untuk dilakukan analisis faktor. Setelah semua variabel dinyatakan layak untuk analisis faktor, dilanjutkan dengan melakukan ekstrasi faktor berdasarkan kriteria eigen value untuk mendapatkan jumlah faktor yang terbentuk. Metode yang dapat digunakan dalam ekstrasi faktor antara lain adalah Principal Component Analysis. Setelah didapatkan jumlah kelompok faktor dominan yang terbentuk, dilakukan rotasi faktor yang bertujuan agar dapat memperoleh struktur faktor yang lebih sederhana agar mudah diinterpretasikan. Tahap terakhir dari analisis faktor adalah menginterpretasi hasil dari analisis faktor tersebut yang dapat dilakukan dengan mengetahui variabel pembentuknya. Pada analisis data dapat dilakukan dengan bantuan program SPSS.

\section{Faktor-Faktor Dominan yang Perlu dipertimbangkan Dalam Penerapan Model Rencana Insentif}

Di tahapan faktor yang mempengaruhi, bedasarkan hasil data yang diolah pada aplikasi SPSS didapat faktorfaktor dominan yang perlu dipertimbangkan dalam penerapan rencana insentif

\section{HASIL DAN DISKUSI}

\section{Validasi Pakar}

Dari hasil validasi ahli diperoleh 17 variabel yang disetujui yang kemudian digunakan sebagai variabel dalam kuesioner. Tabel 3 merupakan variabel yang diperoleh dari hasil validasi ahli. Terdapat 5 orang Jumlah ahli yang diajukan pada penelitian ini.

Tabel 3. Variabel yang disetujui oleh pakar

\begin{tabular}{cl}
\hline Kode & \\
\hline X1 & Etika profesional mempengaruhi rencana insentif untuk pengurangan material sisa \\
X2 & $\begin{array}{l}\text { Tingkat motivasi pekerja lapangan mempengaruhi rencana insentif untuk pengurangan material } \\
\text { sisa }\end{array}$ \\
X3 & Tingkat motivasi stakeholder mempengaruhi rencana insentif untuk pengurangan material sisa \\
X4 & Rencana insentif dipengaruhi oleh keefektifan karena metode ini dinilai lebih efektif ketimbang \\
& memberikan sanksi hukuman untuk pengurangan material sisa \\
X5 & Efisiensi pekerja lapangan mempengaruhi rencana insentif untuk pengurangan material sisa \\
X6 & Kinerja pekerja lapangan yang baik mempengeruhi rencana insentif untuk pengurangan material \\
& sisa \\
X7 & Penerapan rencana insentif secara meluas untuk membangun proyek akan menghemat lebih \\
& banyak material sisa \\
X8 & Suatu anggaran proyek mempengaruhi rencana insentif untuk pengurangan material sisa \\
X9 & Biaya proyek mempengaruhi rencana insentif untuk pengurangan material sisa \\
X11 & Pencapaian tujuan kinerja pekerja lapangan mempengaruhi rencana insentif untuk pengurangan \\
X12 & material sisa \\
X13 & Wawasan para pekerja lapangan mempengaruhi rencana insentif untuk pengruangan material sisa \\
X14 & Sedikitnya permasalahan dalam proyek mempengaruhi rencana insentif untuk pengurangan \\
X15 & material sisa \\
& Peningkatan kualitas pekerja lapangan mempengaruhi rencana insentif untuk pengurangan \\
X16 & material sisa \\
X17 & Sedwal proyek mempengaruhi rencana insentif untuk pengurangan material sisa \\
X18 & pengurangan material sisa \\
& Efisiensi pekerjaan kontraktor mempengaruhi rencana insentif untuk pengurangan material sisa \\
\hline
\end{tabular}




\section{Data kuesioner}

Selanjutnya, kuesioner disebarkan kepada 32 responden yang merupakan pelaku proyek dari kontraktor proyek. Dalam penelitian ini, peneliti berhasil mengumpulkan sebanyak 30 tanggapan responden. Karakteristik posisi responden di proyek tersebut terbagi menjadi seperti pada Tabel 3 dibawah ini.

Tabel 4. Karakteristik responden berdasarkan posisi atau jabatan di proyek

\begin{tabular}{cc}
\hline Posisi/Jabatan di Proyek & Jumlah Responden \\
\hline Project Manager & 5 \\
Project Coordinator & 1 \\
Quantity Surveyor & 16 \\
Cost Control & 1 \\
Direktur & 2 \\
Owner Perusahaan & 1 \\
Pengawas Lapangan & 2 \\
\hline
\end{tabular}

Untuk mengukur nilai kuesioner digunakan teknik pengukuran Likert untuk skala pengukuran faktor dominan yang perlu diperhatikan dalam penerapan model perencanaan insentif tercantum pada tabel 5.

Tabel 5. Deskripsi Skala Likert

\begin{tabular}{cc}
\hline Skala & Keterangan \\
\hline 1 & Sangat Tidak Berpengaruh \\
2 & Tidak Berpengaruh \\
3 & Netral \\
4 & Berpengaruh \\
5 & Sangat Berpengaruh \\
\hline
\end{tabular}

Tabel 6 dibawah ini merupakan data hasil kuesioner yang didapat dari para responden, sebagai berikut:

Tabel 6. Data hasil kuesioner

\begin{tabular}{|c|c|c|c|c|c|c|c|}
\hline \multirow[t]{2}{*}{ No } & \multirow[t]{2}{*}{ Kode } & \multirow[t]{2}{*}{ Pertanyaan } & \multicolumn{5}{|c|}{ Skala } \\
\hline & & & 1 & 2 & 3 & 4 & 5 \\
\hline 1 & $\mathrm{X} 1$ & $\begin{array}{l}\text { Etika profesional mempengaruhi rencana insentif untuk } \\
\text { pengurangan material sisa }\end{array}$ & 1 & 1 & 5 & 16 & 7 \\
\hline 2 & $\mathrm{X} 2$ & $\begin{array}{l}\text { Tingkat motivasi pekerja lapangan mempengaruhi rencana } \\
\text { insentif untuk pengurangan material sisa }\end{array}$ & 0 & 1 & 2 & 16 & 11 \\
\hline 3 & X3 & $\begin{array}{l}\text { Tingkat motivasi stakeholder mempengaruhi rencana insentif } \\
\text { untuk pengurangan material sisa }\end{array}$ & 0 & 3 & 7 & 14 & 6 \\
\hline 4 & $\mathrm{X} 4$ & $\begin{array}{l}\text { Rencana insentif dipengaruhi oleh keefektifan karena metode ini } \\
\text { dinilai lebih efektif ketimbang memberikan sanksi hukuman untuk } \\
\text { pengurangan material sisa }\end{array}$ & 1 & 2 & 9 & 11 & 7 \\
\hline 5 & X5 & $\begin{array}{l}\text { Efisiensi pekerja lapangan mempengaruhi rencana insentif untuk } \\
\text { pengurangan material sisa }\end{array}$ & 0 & 2 & 11 & 12 & 5 \\
\hline 6 & X6 & $\begin{array}{l}\text { Kinerja pekerja lapangan yang baik mempengeruhi rencana } \\
\text { insentif untuk pengurangan material sisa }\end{array}$ & 0 & 1 & 4 & 15 & 10 \\
\hline 7 & $\mathrm{X} 7$ & $\begin{array}{l}\text { Penerapan rencana insentif secara meluas untuk membangun } \\
\text { proyek akan menghemat lebih banyak material sisa }\end{array}$ & 1 & 4 & 11 & 11 & 3 \\
\hline 8 & $\mathrm{X} 8$ & $\begin{array}{l}\text { Suatu anggaran proyek mempengaruhi rencana insentif untuk } \\
\text { pengurangan material sisa }\end{array}$ & 1 & 4 & 4 & 14 & 7 \\
\hline 9 & X9 & $\begin{array}{l}\text { Biaya proyek mempengaruhi rencana insentif untuk pengurangan } \\
\text { material sisa }\end{array}$ & 0 & 3 & 7 & 17 & 3 \\
\hline
\end{tabular}


(Lanjutan) Tabel 5. Data hasil kuesioner

\begin{tabular}{|c|c|c|c|c|c|c|c|}
\hline \multirow[t]{2}{*}{ No } & \multirow[t]{2}{*}{ Kode } & \multirow[t]{2}{*}{ Pertanyaan } & \multicolumn{5}{|c|}{ Skala } \\
\hline & & & 1 & 2 & 3 & 4 & 5 \\
\hline 10 & $\mathrm{X} 11$ & $\begin{array}{l}\text { Pencapaian tujuan kinerja pekerja lapangan mempengaruhi } \\
\text { rencana insentif untuk pengurangan material sisa }\end{array}$ & 0 & 2 & 10 & 12 & 6 \\
\hline 11 & X12 & $\begin{array}{l}\text { Wawasan para pekerja lapangan mempengaruhi rencana insentif } \\
\text { untuk pengruangan material sisa }\end{array}$ & 0 & 3 & 6 & 15 & 6 \\
\hline 12 & $\mathrm{X} 13$ & $\begin{array}{l}\text { Wawasan para stakeholder mempengaruhi rencana insetif untuk } \\
\text { pengurangan material sisa }\end{array}$ & 1 & 1 & 10 & 11 & 5 \\
\hline 13 & X14 & $\begin{array}{l}\text { Sedikitnya permasalahan dalam proyek mempengaruhi rencana } \\
\text { insentif untuk pengurangan material sisa }\end{array}$ & 0 & 3 & 11 & 14 & 2 \\
\hline 14 & X15 & $\begin{array}{l}\text { Peningkatan kualitas pekerja lapangan mempengaruhi rencana } \\
\text { insentif untuk pengurangan material sisa }\end{array}$ & 1 & 0 & 4 & 18 & 7 \\
\hline 15 & X16 & $\begin{array}{l}\text { Jadwal proyek mempengaruhi rencana insentif untuk pengurangan } \\
\text { material sisa }\end{array}$ & 0 & 8 & 6 & 13 & 3 \\
\hline 16 & X17 & $\begin{array}{l}\text { Sedikitnya kecacatan yang muncul pada proyek mempengaruhi } \\
\text { rencana insentif untuk pengurangan material sisa }\end{array}$ & 0 & 3 & 9 & 13 & 6 \\
\hline 17 & X18 & $\begin{array}{l}\text { Efisiensi pekerjaan kontraktor mempengaruhi rencana insentif } \\
\text { untuk pengurangan material sisa }\end{array}$ & 1 & 4 & 15 & 6 & 4 \\
\hline
\end{tabular}

Pada tahap ini juga penulis meminta pendapat kepada setiap responden mengenai rencana insentif terhadap material sisa apakah rencana insentif ini dinilai sangat tepat dan dapat mengurangi material sisa jawaban bervariatif ada yang setuju secara mutlak bahwa rencana insentif dinilai sangat tepat dan dapat mengurangi material sisa, ada yang setuju namun lebih setuju menggunakan cara lain yang lebih tepat dan efektif untuk pengurangan material sisa, serta ada yang tidak setuju mengenai rencana insentif ini karena di nilai sulit untuk dilaksanakan karena tidak ada kepastian hukum yang jelas di indonesia.

\section{Uji validitas, Uji reliabilitas, dan Uji normalitas}

Uji validitas dilakukan dengan metode bivariate. Variabel akan dinyakan valid apabila nilai pearson correlation atau r hitung pada suatu variabel lebih besar daripada nilai r product moment dari tabel. Data sampel yang digunakan dalam penelitian ini adalah $30(\mathrm{~N}=30)$ dan taraf signifikansi yang digunakan sebesar 5\%, maka dengan melihat tabel nilai r product moment diperoleh nilai $r$ sebesar 0,361. Kemudian $r$ hitung diperoleh dengan menggunakan software SPSS apabila $r$ hitung yang didapat lebih besar dari syarat $r$ tabel maka data valid. Tabel 6 merupakan hasil dari uji validitas sebagai berikut.

Tabel 6. Hasil Output Bivariate Variabel

\begin{tabular}{cccc}
\hline Variabel & Pearson Correlation & Syarat r Tabel & Keterangan \\
\hline X1 & 0,416 & 0,361 & VALID \\
X2 & 0,447 & 0,361 & VALID \\
X3 & 0,626 & 0,361 & VALID \\
X4 & 0,653 & 0,361 & VALID \\
X5 & 0,736 & 0,361 & VALID \\
X6 & 0,598 & 0,361 & VALID \\
X7 & 0,549 & 0,361 & VALID \\
X8 & 0,650 & 0,361 & VALID \\
X9 & 0,371 & 0,361 & VALID \\
X11 & 0,485 & 0,361 & VALID \\
X12 & 0,602 & 0,361 & VALID \\
X13 & 0,511 & 0,361 & VALID \\
X15 & 0,595 & 0,361 & VALID \\
\hline
\end{tabular}

Kemudian melakukan uji reliabilitas untuk 13 variabel digunakan untuk menentukan reliabel atau tidaknya suatu instrumen penelitian dengan menghitung nilai koefisien Cronbach's Alpha.Dari hasil analisis didapatkan nilai Cronbach's Alpha sebesar 0,815 sehingga instrumen pengumpulan data (kuesioner) dapat dikatakan reliabel $(>0,6)$. Setelah uji reliabilitas, dilakukan uji normalitas dan didapatkan hasil nilai signifikansi sebesar 0,200 sehingga data dapat dikatakan terdistribusi normal $(>0,05)$. 


\section{Analisis Faktor}

Setelah melakukan uji validitas, reliabilitas, dan normalitas, selanjutnya dilakukan analisis faktor terhadap 13 variabel yang valid. Pada tahapan ini digunakan metode analisis faktor karena dengan metode ini dapat diketahui faktor faktor dominannya dan me-reduce faktor agar lebih applicable. Setelah melakukan analisis faktor diketahui hanya 8 varibael yang dapat di jadikan sebagai faktor dominan dalam penerapan rencana insentif. Dari hasil initial eigen value menunjukan ada 3 kelompok faktor dominan yang akan terbentuk, yaitu faktor 1, 2, dan 3. Nilai eigen value dari setiap komponen terdapat pada Gambar 1 di bawah ini.

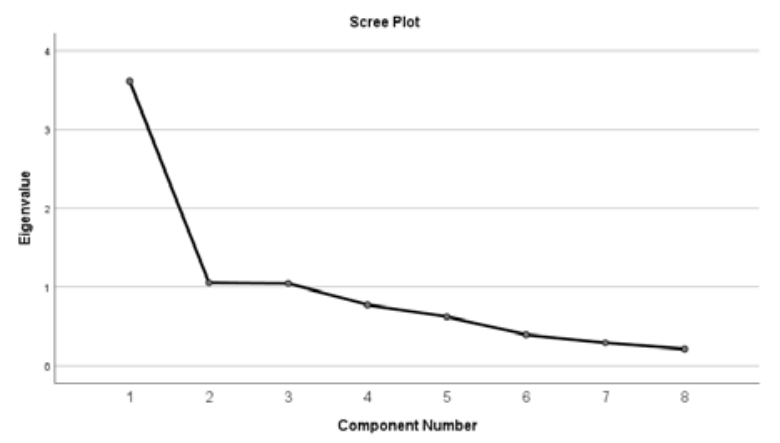

Gambar 1. Scree plot

Pada faktor 1 dengan besar variansi yang bisa diterangkan sebesar 45,175\%, oleh faktor 2 sebesar 13,1625\%, dan oleh faktor 3 sebesar 13,0625\%. Ketiga faktor tersebut kemudian ditotal dan akan mampu menjelaskan variabel sebesar 71.4\%. Setelah mengetahui bahwa jumlah kelompok faktor dominan maksimal yang bisa terbentuk adalah 3 buah faktor, selanjutnya dilakukan penentuan kelompok masing-masing faktor dominan yang akan masuk ke dalam kelompok faktor 1, faktor 2, atau faktor 3. Cara menentukannya adalah dengan melihat tabel rotated komponen matriks pada tabel 7 sebagai berikut.

Tabel 7. Hasil rotated component matrix

\begin{tabular}{cccc}
\hline Component & 1 & 2 & 3 \\
\hline X4 & 0,809 & 0,173 & 0,230 \\
X5 & 0,815 & 0,327 & 0,115 \\
X6 & 0,849 & 0,051 & 0,232 \\
X7 & 0,055 & 0,875 & 0,135 \\
X8 & 0,214 & 0,616 & 0,435 \\
X15 & 0,480 & 0,670 & $-0,068$ \\
X3 & 0,084 & 0,150 & 0,833 \\
X12 & 0,286 & 0,059 & 0,721 \\
\hline
\end{tabular}

Dalam menentukan variabel input terhadap suatu faktor tertentu diikuti korelasi antar variabel dengan masingmasing kelompok faktor, yaitu variabel yang mempunyai nilai korelasi terbesar terhadap kelompok faktor. Dengan demikian, dapat disimpulkan bahwa kelompok faktor dan faktor dominannya adalah: Kelompok faktor 1, terdiri dari faktor dominan X4, X5, X6. Sedangkan kelompok faktor 2 terdiri dari faktor dominan X7, X8 dan X15. Untuk faktor kelompok faktor 3 disusun atas X3 dan X12.

\section{KESIMPULAN DAN SARAN}

\section{Kesimpulan}

Terdapat 3 kelompok faktor dominan yang dapat dipertimbangkan dalam menerapkan model rencana insentif untuk material sisa, pertama terdiri dari faktor dominan berupa rencana insentif dipengaruhi oleh keefektifan karena metode ini dinilai lebih efektif ketimbang memberikan sanksi hukuman untuk pengurangan material sisa, Efisiensi pekerja lapangan mempengaruhi rencana insentif pengurangan material sisa, Kinerja pekerja lapangan yang baik mempengaruhi rencana insentif untuk pengurangan material sisa. Kelompok faktor dominan kedua terdiri dari faktor-faktor dominan seperti Penerapan rencana insentif secara meluas untuk membangun proyek akan menghemat lebih banyak material sisa, Suatu anggaran proyek mempengaruhi rencana insentif untuk pengurangan material sisa, 
Peningkatan kualitas pekerja lapangan mempengaruhi rencana insentif untuk pengurangan material sisa. Kelompok faktor ketiga terdiri dari faktor dominan berupa rencana insentif yang dipengaruhi oleh Tingkat motivasi stakeholder mempengaruhi rencana insentif untuk pengurangan material sisa dan Wawasan para pekerja lapangan mempengaruhi rencana insentif untuk pengurangan material sisa. Faktor pertama merupakan kelompok faktor yang paling dominan diantara ketiga faktor yang terbentuk dengan nilai sebesar 45,175\%, disusul oleh faktor kedua dengan persentase 13,1625\%, kemudian disusul oleh faktor ketiga dengan nilai sebesar 13,0625\%, ketiga faktor tersebut dapat dipertimbangkan dalam penerapan perancangan model rencana insentif pada material sisa. Dari hasil data penelitian yang bisa dijadikan factor dominan dalam penerapan rencana insentif terdapat variable X6 (Kinerja pekerja lapangan yang baik mempengeruhi rencana insentif untuk pengurangan material sisa) dan variable X15 (Peningkatan kualitas pekerja lapangan mempengaruhi rencana insentif untuk pengurangan material sisa) yang paling disetujui oleh para responden sebagai variable yang perlu dipertimbangkan dalam penerapan rencana insentif sedangkan untuk variable X7 (Penerapan rencana insentif secara meluas untuk membangun proyek akan menghemat lebih banyak material sisa) merupakan variable yang paling sedikit disetujui oleh para respoden untuk penerapan rencana insentif.

\section{Saran}

Hasil penelitian ini dapat dikembangkan dengan cara memperluas perspektif, bukan hanya dari sudut pandang kontraktor, melainkan dapat ditinjau dari sudut pandang pemberi kerja (owner) dan direktur secara meluas. Selain itu, penelitian juga dapat dilakukan dengan menggunakan teknik selain analisis faktor untuk mendapatkan faktorfaktor yang dominan. Sementara itu, dari segi responden juga bisa diperluas tidak hanya di sekitar Jakarta saja, mana perlu sampai keluar pulau jawa secara meluas. faktor-faktor pengaruh pada penelitian dapat dibuat lebih luas lagi yang berkaitan dengan rencana insentif.

\section{DAFTAR PUSTAKA}

Aulia, H. N. (2016). Analisis dan Evaluasi Sisa Material Konstruksi Menggunakan Metode Pareto dan Fishbone Diagram (Studi Kasus Pada Proyek Pembangunan Gedung PascaSarjana Universitas Negeri Malang). studentjournal, 1(2), 350-1118.

Begum, S. P. (2009). Attitude and behavioral factors in waste management in the construction industry of Malaysia. elsevier, 53, 321-328.

Bower, A. G. (2002). Incentive Mechanisms for Project Success. ASCE, 18(1), 37-43.

Broome, P. (2002). How Practitioners Set Share Fractions In Target Cost Contrats. elsevier, 20(1), 59-66.

Chokor, A. P. (2017). Quantifying the Impact of Cost-Based Incentives on the Performance of Building Projects in the United States. ASCE, 22(2), 04016024.

Devia, U. S. (2010). Identifikasi Sisa Material Konstruksi Dalam Upaya Memenuhi Bangunan Berkelanjutan. Rekayasa Sipil, 4(3), 1978-5658.

Gavilan, R. B. (1994). Source evaluation of solid waste in building construction. ASCE, 120(3), 536-552.

Herliana, A. N. (2017). Pengaruh Insentif Terhadap Peningkatan Kualitas Kerja Karyawan Pada PT BOSOWA BERLIAN MOTOR. Jurnal Riset Edisi 18, 3(7), 96-109.

Karakhan, G. (2018). Hazards and Risk in Construction and the Impact of Incentives and Rewards on Safety Outcomes. ASCE, 23(2), 04018005.

Llatas. (2011). A model for quantifying construction waste in projects according to the European waste list. PudMed, 31(6), 1261-76.

Mahpour, M. (2018). Financial-Based Incentive Plan to Reduce Construction Waste. ASCE, 144(5).

Mustafa. (2017). Studi Tentang Pemberian Insentif Dalam Meningkatkan Kinerja Pegawai Di Sekretariat Daerah Provinsi Kalimantan Timur. Jurnal Paradigma, 1(3), 373-388.

Ogwueleka, M. (2013). A Review of Incentive Issues in South African Construction Industry: The Prospects and Challenges. ASCE, 83-98.

Poon, Y. W. (2013). Quantifying the Impact of Construction Waste Charging Scheme on Construction Waste Management in Hong Kong. ASCE, 22(2), 04016024.

Priyatno, D. (2018). SPSS Panduan Mudah Olah Data Bagi Mahasiswa dan Umum. Yogyakarta: Andi.

Putra, H. (2017). Pengaruh Pemberian Insentif Terhadap Kinerja Karyawan Di PT. Bank Rakyat Indonesia (Persero) Tbk. JRM, 136-154.

Roger, L. S. (1992). Financial Incentive Programs For Avarage-Size Construction Firm. ASCE, 118(4), 667-676.

Sarli, A. (2017). Kajian Pemberian Insentif Dalam Proyek Konstruksi dari Persepsi Pengguna Jasa dan Penyedia Jasa. Kampus Bukit Jimbaran-Bali, 17(1), 1411-129.

Tang, Q. D. (2008). Incentives in the Chinese Construction Industry. ASCE, 134(7), 457-467.

Tchobanoglous, \& Theisen. (1993). Integrated solid waste. New Jersey: McGraw-Hill. 